\title{
Condition of shrimp culture ponds in the South Coast of Cilacap Regency, Central Java, Indonesia
}

\author{
Ardhana Reswari $\mathrm{Utami}^{1}$, Bambang Widigdo $^{2}$, Sulistiono ${ }^{2}$ \\ ${ }^{1}$ Study Program of Coastal and Marine Resources Management, Graduate School, Bogor \\ Agricultural University, 16680 Bogor, Indonesia \\ ${ }^{2}$ Department of Aquatic Resources Management, Faculty of Fisheries and Marine Sciences, Bogor \\ Agricultural University, Bogor 16680, Indonesia
}

\begin{abstract}
In recent years, aquaculture has begun to develop on the southern coast of Cilacap, which is carried out on sandy land without being surrounded by mangroves and is generally operated with intensive methods. This pool is owned by individuals or companies. This paper aims to descriptively describe aquaculture condition in the area, especially regarding the status, production, and management efforts, based on the results of field observations and literature studies. The area of intensive shrimp cultivation in Cilacap Regency in 2020 is \pm 227 ha, and the number of cultivators (intensive) is 270 people. The overall value of shrimp production in 2018 in Cilacap Regency was Rp. 52,898,856,945.00, an increase of 38\% compared to 2017 , which was Rp. 38,446,305.875.00. Adipala Regency has a large pond area, but the production value and production are less than other districts. In the development of ponds, some locations are made quite close to the beach, without a green belt. Seawater is taken directly from the sea by suction using a pump or by drilling. Likewise, freshwater extraction is carried out through drilling into the ground. Wastewater is discharged directly into the sea because there is no Wastewater Treatment Plant (WWTP).
\end{abstract}

\section{Introduction}

The coastal area is a dividing space between land and sea areas. Therefore, this area is unique geologically and is the highest level in the taxon, which is very important for many lives on land and in water, including humans [1]. Coastal areas have diverse natural resources with various functions, namely agriculture, fisheries, settlements, ports, tourism, and/or industry. Environmentally friendly and sustainable coastal management systems must be used as the basis for developing coastal areas, both for aquaculture and other sector activities [2]. Aquaculture is one of the fastest-growing food production sectors. Globally, this production continues to increase. $89 \%$ of aquaculture production comes from Asia $89 \%$. Some of the main producing countries include China, Bangladesh, Chile, Egypt, India, Indonesia, 
Norway, and Vietnam. In 2018, Indonesia was ranked 2nd for capture fisheries production and global aquaculture production [3]. As an archipelagic country, Indonesia has approximately 16,771 islands consisting of large and small islands, and the total coastline is estimated to be $108,000 \mathrm{~km}$ [4]. This indicates the potential for cultivation in Indonesia is very large.

Shrimp is one of Indonesia's leading commodities because it has a high selling value and demand in the international market. Its cultivation technology has been mastered by most farmers [5]. Based on the ministry of marine and fisheries data in 2018, shrimp was still Indonesia's first leading export commodity in 2018, with a total volume of 146,164,096.07 $\mathrm{kg}$. In terms of value, shrimp contributed to foreign exchange of USD 1.3 billion or $36.96 \%$ of the total export value [6]. The rapid growth of shrimp farming raises questions about the environmental impact. With the opening of ponds, coastal areas are under pressure, and the process of changing environmental conditions is very fast. The rapid rate of land-use change causes changes in ecosystems, coastal typology, characteristics, and carrying capacity of the land, and the potential of aquaculture areas [7]. This concern arises because pond management cannot be separated from unsustainable cultivation systems.

Aquaculture, in general, has contributed to the loss of mangrove ecosystems by $58 \%$. Shrimp farming contributed the most, as much as $41 \%$. Previously, almost all shrimp pond cultivation was carried out in mangrove forest areas because the soil structure was impervious to water. Currently, the expansion of shrimp farming has penetrated marginal lands in the last decade on the southern coast of Java, especially in sandy lands that have been underutilized [8]. The results of a study by Suadi and Saksono (2014) show that the development and availability of aquaculture technology adaptive to the location and the increasing demand for shrimp markets encourage the rapid conversion of sandy lands into shrimp ponds. In preventing/reducing the reduction rate of mangrove forests due to the development of shrimp ponds [9], Widigdo (2013) describes the technology of shrimp ponds on sandy soil called the BIOCRETE pond technique. Therefore, to maintain its predicate as one of the producers of aquaculture shrimp, it has finally begun to develop pond cultivation on sandy land. Land requirements for the construction of Biocrete are very different from those in general. The main requirement is the high content of sand. Areas with sandy conditions usually have no agrarian economic value, so that their use for ponds does not have a conflict of interest with agricultural activities. Usually, there is no green belt [5].

Cilacap Regency is one of the regencies located in the south of Java Island. Cilacap Regency is geographically located at $108^{\circ} 57^{\prime} 51.66^{\prime \prime}$ East Longitude - 109 $23^{\prime} 38.87^{\prime \prime}$ East Longitude and $7^{\circ} 37^{\prime} 2.77^{\prime \prime}$ South Latitude - $7^{\circ} 47^{\prime} 4.68^{\prime \prime}$ South Latitude. It consists of 24 districts [10], eight of which have coasts, and 6 of them are located on the coast directly facing the Indian Ocean. The six districts include Cilacap Selatan, Cilacap Utara, Kesugihan, Adipala, Binangun and Nusawungu Districts. After about five years along the southern coast of Cilacap, it has been used for vaname shrimp farming activities. Utilization of coastal areas as shrimp pond farming land must be managed in such a way that it meets various sustainability principles.

Based on the description above, it is necessary to know the condition/management of shrimp ponds in the southern coastal area of Cilacap, used for shrimp pond culture, to minimize the impact and overcome these impacts. The purpose of this paper is to describe the condition of aquaculture descriptively, especially regarding the status, production, problems, and management efforts. 


\section{Location and methods}

\subsection{Time and location}

Field observations were carried out for three months, from April to June 2021. The location includes six districts located on the southern coast of Cilacap, which are directly facing the Indian Ocean, including the Districts of Cilacap Selatan, Cilacap Utara, Kesugihan, Adipala, Binangun, and Nusawungu (Fig 1.). Specifically, Cilacap Utara District has two coasts, namely in the west of Cilacap, which includes the Segara Anakan lagoon area, and a small part on the south coast of $\pm 1.34 \mathrm{~km}$ is adjacent to Cilacap Selatan District and Kesugihan District. Observations were divided into two legs, namely A B C and D E F, which were bounded by the mouth of the Serayu River. This division is based on the differences in the characteristics of farming and making of the pond.

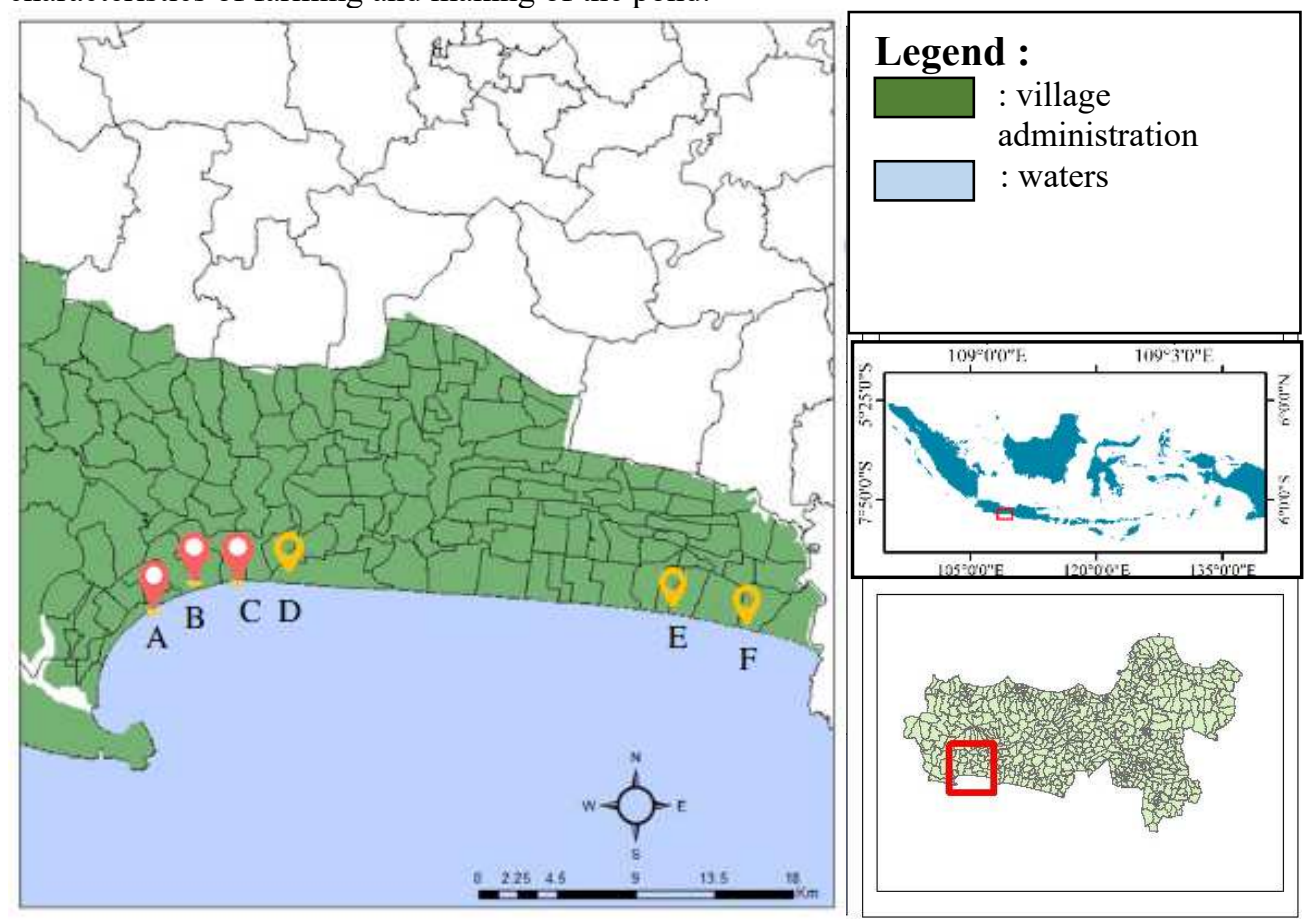

Fig. 1. Observation Locations on the southern coast of Cilacap, Central Java, Indonesia.

Description :

Location A : Tegalkamulyan Village, Cilacap Selatan District

Location B : Lengkong Hamlet, Mertasinga Village, Cilacap Utara District

Location C : Menganti Village, Kesugihan District

Location D : Bunton Village, Adipala District

Location E : Pagubugan Village, Binangun District

Location F : Banjarsari Village, Nusawungu District

\subsection{Methods}

This paper is in the form of data processing either through direct observation or literature review. Then the analysis was carried out descriptively, describing the condition that exists 
at the location, followed by analyzing the problems encountered. The survey was conducted to collect limited data from a large number of cases. Furthermore, the data obtained is used to solve the problem without testing the hypothesis [11].

Data collection was carried out by direct observation in the field and interviews with pond managers $(n=10)$ from several locations and with the Fisheries office of Cilacap Regency, including the related District Fisheries Extension Officer. In addition, secondary data was used in the form of data from related agencies such as data from the Cilacap Regency Fisheries Service, data from the Central Statistics Agency for Cilacap Regency, data from Meteorological, Climatological, and Geophysical Agency, and also supporting literature.

\section{Results and discussion}

\subsection{General condition}

The South Coast of Cilacap coastline of $\pm 45 \mathrm{~km}$ with a black sand substrate, with occasional muddy beaches, especially around river mouths. On this sandy beach, it is currently widely used for vaname shrimp pond farming. High currents and waves characterize the hydrooceanographic conditions in South Java. The average current speed is $0.6 \mathrm{~m} / \mathrm{s}$ [9]. The wave height ranges from 1.25 to $3 \mathrm{~m}$. This is because the waters of Cilacap are a bay area, so the waves are not as high as in other waters in Southern Java. Based on Handoyo et al. (2015) can be categorized that Cilacap waters have mixed tidal types, which tend to occur twice a day [12]. Based on data from Meteorological, Climatological of the Cilacap Regency from April to June 2020, the average high tide is $1.63 \mathrm{~m}$, and the lowest low tide is 0.5 . The tidal range is calculated from the average high tide level to the lowest low tide, which is around $1.09 \mathrm{~m}$. Meanwhile, based on Suhana (2018), the salinity values of the southern waters of Java range is \pm 34 grams/liter, and water temperature is between $20-30^{\circ} \mathrm{C}$ depending on the season [13].

In a previous study, Kasari et al. (2017) calculated several physical and chemical parameters around the Segara Anakan estuary. Compared to the Segara Anakan estuary area, the temperature of the waters near the high seas is lower than that around the Segara Anakan lagoon. The temperature near the high seas is $28.32^{\circ} \mathrm{C}$, while in the lagoon it is $29.07^{\circ} \mathrm{C}$. The water temperature is still in the range of $28-32^{\circ} \mathrm{C}$, which is following the quality standard in the Decree of the State Minister of the Environment (Kepmen LH) No. 51 of 2004. This means that the condition of the waters is still good [14].

In general, coastal conditions in the Coastal District of Cilacap Regency have sandy beach characteristics with a slope ranging from $3.5 \%$ to $11.9 \%$. Characteristics of sandy beaches on the coast of Cilacap Regency can be found almost along the coast, with occasional slightly muddy beaches, especially around river mouths. Sandy beaches and muddy beaches generally have a small coastal slope, so the beach will be very vulnerable to changes in coastline due to erosion and accretion [10].

Based on direct observations in the field and interviews with local farmers and fisheries extension workers, no mangrove forest was found in the southern coastal area of Cilacap because it is a sandy area, the sand content is estimated to be $>90 \%$. The species composition of the most macrozoobenthos toward in south of coastal is the genus Gastropod, Tagelus sp. and Tellina sp. and Bivalves of Pyramidella sp., Mitra sp., and Buccinum sp. While the genus polychaeta is not too much, only the type Nereis sp. and Terebra sp. This is because the substrate on the coast of Cilacap is a type of sandy loam with a predominance of $86.85 \%$ sand, $5.35 \%$ silt, and $7.8 \%$ clay [15]. So that people use the land to develop shrimp ponds with Biocrete technology. The commodity cultivated in the pond is vaname shrimp (Litopenaeus vannamei) which is carried out intensively. 


\subsection{Ownership status}

In terms of authority, the southern coast of Java, especially Central Java, is under the authority of the Ministry of Defense which is managed by the Diponegoro Military Regional Command (KODAM IV) Central Java Province, so that most of the ponds on the southern coast of Cilacap were built on land owned by the army with a rental system for 30-40 million / ha per year, while the pond which is farther from the beach is built on community land. The land lease system also occurs in the Kulonprogo area, Yogyakarta at a cost of around Rp. 36.566.857,00. The difference is that in Yogyakarta the land authority belongs to the Sultan Ground or land belonging to the Ngayogyakarta Hadiningrat Sultanate and is managed for the benefit of the community's welfare. Some are built on private land [16]. Individual communities own pond ponds along the coast or some are owned by companies such as CV. Lautan Mas Jaya in Widarapayung, Binangun District, Berkah Laut Abadi Shrimp Pond in Pagubugan, Binangun District and CV Cemara Sewu Sumber Rejeki in Jetis, Nusawungu District (Table 1). Some of the privately owned pools in Cilacap Regency are owned by local people who work on their own or outsiders own some, then employ local people or bring in from their area to maintain and maintain the pond. There are at least 1-2 people to manage and maintain 1 pool. CV. Cemara Sewu Sumber Rejeki is a super intensive Vaname shrimp pond with a density of $130 \mathrm{fish} / \mathrm{m} 2$ which is divided into two locations. Block A is an area in Cemara Sewu which borders the Ijo River Estuary. While Block B is an area in Cemara Sewu which borders Jetis [17].

Table 1. Shrimp pond ownership area.

\begin{tabular}{|c|l|c|}
\hline No & \multicolumn{1}{|c|}{ Pond ownership } & Land area (Ha) \\
\hline 1 & Community/individual & 128,81 \\
\hline 2 & CV Lautan Mas Jaya & 35 \\
\hline 3 & CV Cemara Sewu Sumber Rejeki & 18 ha [13] \\
\hline 4 & Berkah Laut Abadi Shrimp Ponds & \pm 5 \\
\hline
\end{tabular}

\subsection{Development of intensive shrimp farms in Cilacap}

Based on data from the Fisheries office of Cilacap Regency in 2020, the number of intensive ponds managed is 227 ha. The area of land in the district continues to increase from 2017 to 2020 (Fig 2). This is also followed by the number of owners of intensive shrimp ponds in Cilacap Regency. In 2017 the owners of intensive ponds are 100 people, while in 2020 it will increase to 270 people.

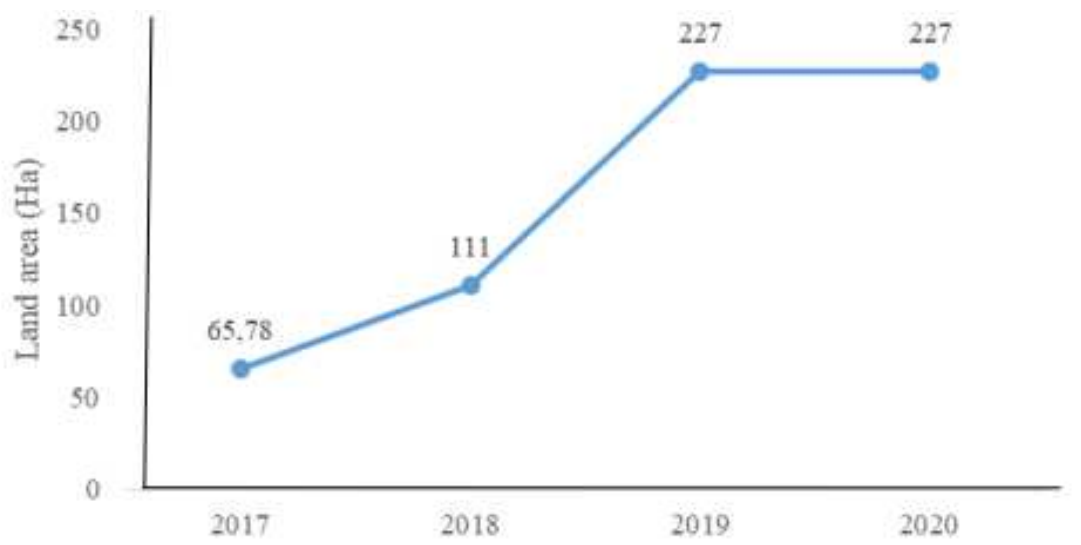

Fig. 2. Changes in the area of intensive shrimp ponds in Cilacap Regency. 


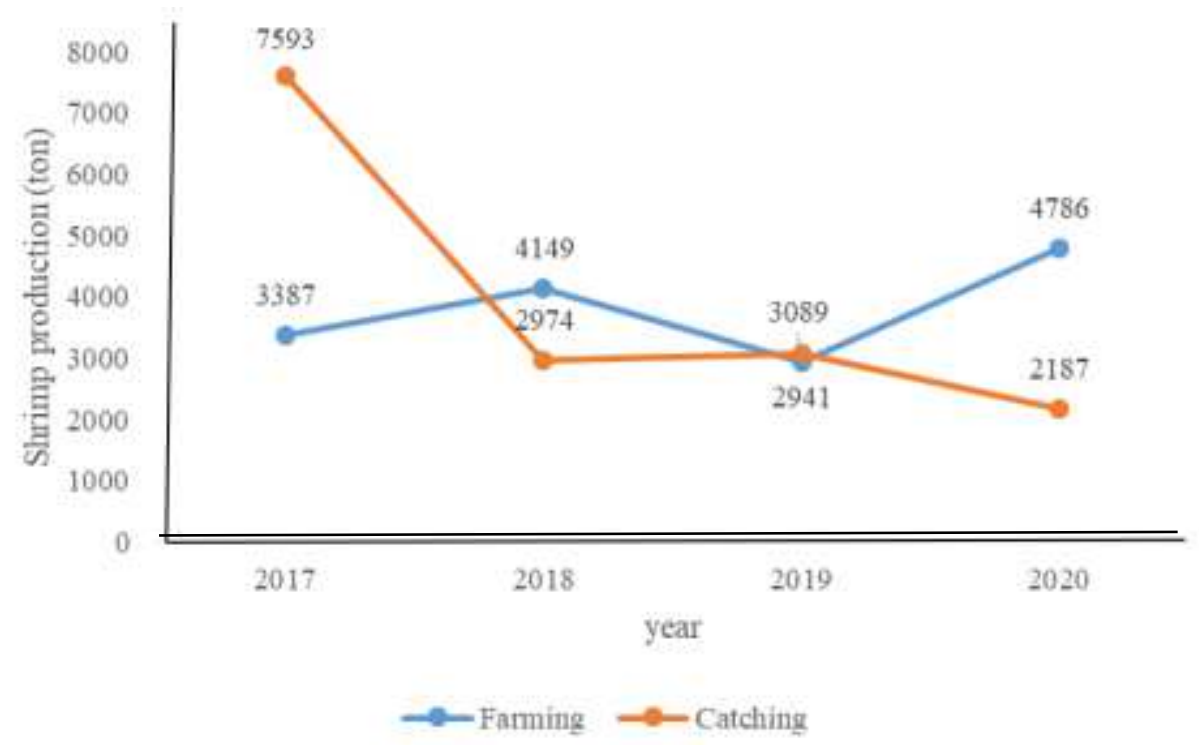

Fig. 3. Changes in shrimp production in Cilacap Regency.

Along with the increase in intensive shrimp ponds, shrimp production from aquaculture in general has increased although it is still fluctuating. In 2017 total production reached 3,387 tons, then increased in 2018 to 4,149 tons, then decreased in 2019 to 2,941 tons and increased again in 2020 to 4,786 tons. The value of shrimp production from aquaculture is higher than from the catch. The details of intensive pond area data from six districts located on the southern coast of Cilacap Regency are as follows (Fig. 4).

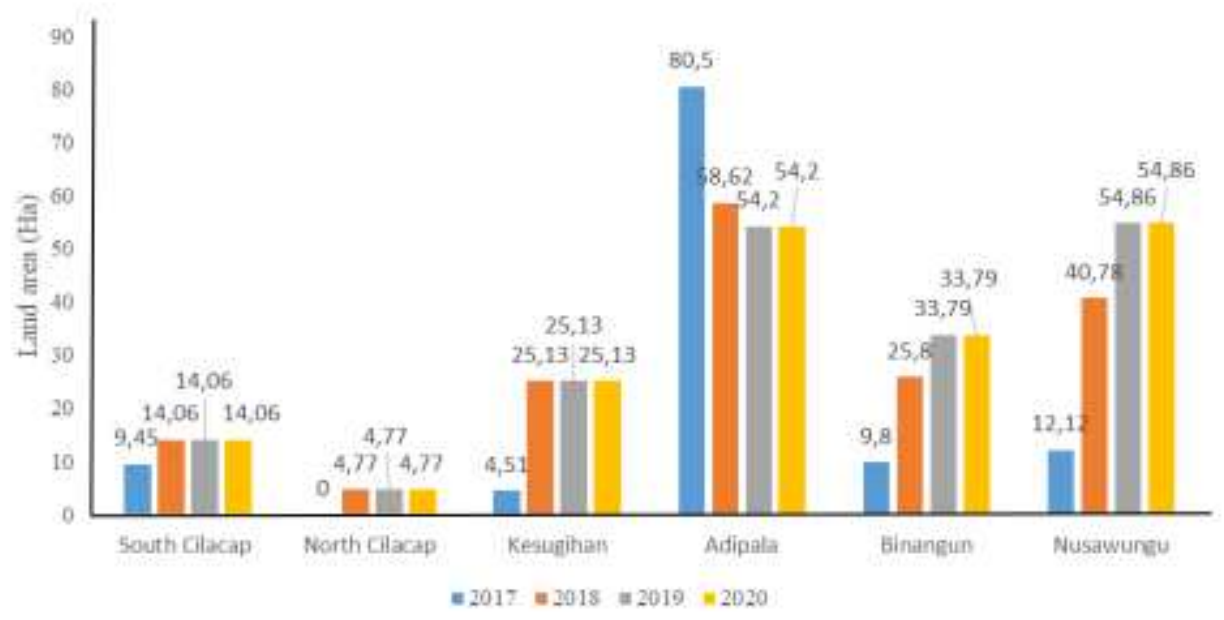

Fig. 4. Changes in the area of intensive shrimp ponds in each southern coastal district of Cilacap Regency.

Based on changes in land area from 2017 to 2020, it can be said that almost the entire area of ponds has increased in land area, except for Adipala District. This is because more and more people are interested in shrimp farming. After all, the results from shrimp ponds are very profitable. In contrast to the Adipala sub-district which experienced a decrease in area. The location of shrimp ponds in Adipala District is around the mouth of the Serayu river and often experiences crop failures so that in 2018 to 2020 the land area has decreased. 
The development and availability of aquaculture technology adaptive to the location and the increasing demand for shrimp markets encourage the rapid conversion of sandy lands into shrimp ponds [9]. The development of intensive shrimp farming does not only occur in Cilacap. Before developing shrimp ponds on sandy land in Cilacap, communities along the South Coast of the Special Region of Yogyakarta (DIY) and Purworejo Regency, Central Java had started to switch to using sandy land to become land for shrimp ponds. The rapid growth of vaname shrimp (Litopenaeus vannamei) farming occurred in the 2013-2014 [8].

Table 2. Development of Farming Production Results and Aquaculture household in Cilacap District

\begin{tabular}{|c|l|c|c|c|c|c|c|}
\hline \multirow{2}{*}{ No } & \multirow{2}{*}{ Districts } & \multicolumn{3}{|c|}{ Production (ton) } & \multicolumn{4}{c|}{ Aquaculture Household (person) } \\
\cline { 3 - 8 } & & 2016 & 2018 & 2017 & 2018 & 2019 & 2020 \\
\hline 1 & Cilacap Selatan & 239,94 & 248,96 & 7 & 10 & 13 & 13 \\
\hline 2 & Cilacap Utara & - & - & - & - & 6 & 6 \\
\hline 3 & Kesugihan & 92,85 & 622,39 & 9 & 25 & 35 & 35 \\
\hline 4 & Adipala & 98,18 & 142,21 & 61 & 73 & 91 & 91 \\
\hline 5 & Binangun & 140,44 & 941,39 & 19 & 19 & 19 & 19 \\
\hline 6 & Nusawungu & 241,41 & $1.618,21$ & 52 & 64 & 64 & 64 \\
\hline
\end{tabular}

Based on Table 2, shrimp production has increased along with the increase in land area. Cilacap Utara sub-district has the least number of fishpond farmers because in Cilacap Utara sub-district only has coastline $\pm 1 \mathrm{~km}$, directly facing the high seas, with several shrimp ponds around 13 ponds and an average pond area of $1600 \mathrm{~m}^{2}$ to $3000 \mathrm{~m}^{2}$.

Adipala Subdistrict, although experiencing a decrease in the pond area, is still quite large because the land is located in the west and east of the mouth of the Serayu River. However, this is not under the small production results when compared to other districts. Currently, in Adipala alone, only about $50 \%$ of active aquaculture ponds of the total existing pond land. In this sub-district, there is also not only intensive farming but also semi-intensive and traditional ponds. Of the total area of 54,2 ha of ponds, the area of intensive ponds is 36,26 ha. Most of the ponds in the Adipala Subdistrict are owned by individuals and residents who initially made ponds because they wanted to benefit from shrimp pond farming. With poor farming knowledge, it is more prone to crop failure. So many of the farmers did not continue and eventually rented out their land. The existence of empty ponds happens not only in Adipala; apart from being rented out, many deliberately vacate it temporarily to wait for an excellent season to sow shrimp seeds.

\subsection{Characteristics of Intensive Ponds on the South Coast of Cilacap}

Overall in the six districts, the average area of shrimp ponds ranges from $1000 \mathrm{~m}^{2}$ to 3000 $\mathrm{m}^{2}$ with an average pond depth of 1 meter. Each pond is usually sown with fry as 200,000250,000 fish per pond with medium size of $1800 \mathrm{~m}^{2}-2000 \mathrm{~m}^{2}$. Meanwhile, in a large pond, around $3000 \mathrm{~m}^{2}$, about 300,000 fries are sown per pond. The seeds used are mainly sourced from several suppliers and collector partnerships, including for feed. Shrimp are usually harvested within an average of 4 months. An early harvest will be carried out if there is a threat of disease or a bad season. The harvests are directly sold to collectors who have collaborated, later exported abroad, rarely from those who sell directly to the market or TPI. Compared with the ponds in Kulonprogo, Yogyakarta, the average ponds cultivated by farmers is $1,624 \mathrm{~m}^{2}$, with the smallest pond area of $500 \mathrm{~m}^{2}$ and the largest pond measuring $2,000 \mathrm{~m}^{2}$. The need for fry per production period ranges from $200,000-225,000$ [16]. It can be said that the characteristics of Cilacap ponds on the southern coast of Cilacap are similar to those in Purworejo and Yogyakarta. 
Shrimp production for one pond ranges from 1 ton to 3 tons for medium-sized ponds. As for large-sized ponds, the production can reach 3 to 8 tons. This depends on water conditions, seasons, and the threat of disasters such as abrasion and tidal waves. During the dry season, the production tends to decrease due to the water temperature being too high.

In the process of irrigating ponds, there are differences between locations. Some seawater sources are taken directly from the sea by drilling and refining. Some are making wells for ponds located far from the coast. Then for the need for freshwater, drilling and making wells near the coast are also carried out. The difference is if freshwater makes a vertical channel into the ground, while the channel is horizontal to the sea for seawater. So to regulate the salinity, you only need to adjust the fresh water and saltwater channels. There is a uniqueness, namely in Cilacap Selatan District, shrimp pond farming only uses seawater, with salinity usually around 20\% even during the dry season it can reach $40 \%$. While in Kesugihan District, some ponds only use water from the ground, namely in ponds located far from the beach.

\subsection{Problems and Solutions}

In making shrimp ponds, the ponds are made very in several locations such as in the Districts of Cilacap Selatan, Cilacap Utara, and Kesugihan (A B C) close to the beach, without greenbelts. The pond is built next to the dam previously made as a barrier to waves entering the mainland. Due to frequent abrasion, the ponds in the area are also more prone to tidal disasters.

In addition, most of the ponds on the southern coast of Cilacap do not have a Wastewater Treatment Plant (WWTP) pond. The wastewater is directly discharged to the beach from shrimp pond waste in Cilacap Selatan, Cilacap Utara, and Kesugihan (A BC). There has been an appeal to pond owners that dispose of their waste directly to the beach. After all, it is easier because it minimizes the cost of constructing a WWTP pond or constructing a channel to a further away river. As for the ponds in Adipala, Binangun, and Nusawungu (DEF) districts, the waste results are discharged into small rivers near the ponds, eventually emptying into the sea, even in Binangun and Nusawungu (EF) districts, many ponds have been made more modern with proper sewerage. Therefore, it can be said that the ponds in Binangun and Nusawungu (E F) districts are better in terms of ecology, economy that supports sustainability compared to other districts.

There are not yet optimal land use also needs to be considered, such as the case in Adipala District. Most of the ponds here are built on community-owned land. The ponds in Binangu and Nusawungu are modern and owned by companies and entrepreneurs. On the other hand, the ponds in Adipala are owned mainly by local people interested in shrimp farming with superficial knowledge. The results are not optimal and lead to many failures, and eventually, many pond farmers have withdrawn.

The role of the government represented by the Fisheries Service of Cilacap Regency, Local Government, Fishery Extension on the development of shrimp ponds in Cilacap is only visible from the role of fishery instructors and the Fisheries Service in supervising, providing socialization, insurance intermediaries, data collection and a forum for pond farmers. The Cilacap government has no authority to regulate the construction of pond ponds. In addition, the role of extension workers and the Fisheries Service is not harmonious and harmonious because most of them feel they do not need and ignore the role of the government. The Extension workers make it challenging to collect data and events due to the lack of participation from pond farmers.

The development and utilization of the pond on the southern coast of Cilacap must be carried out in an integrated program. The development has to pay attention to the role and alignment of stakeholders needed in the development and manufacture of shrimp ponds. The 
local government should make more efforts to get closer to pond owners and managers so that socialization can be received well to understand the creation of ponds and wastewater disposal according to the rules. The local government, including the fisheries agency and the Indonesian Army, has to educate the farmer about spatial planning and making ponds. The shrimp ponds in Cilacap are built better so that the results are also more optimal, avoiding the threat of abrasion and environmental damage.

\section{Conclusion}

The condition of the area and production of shrimp ponds on the southern coast of Cilacap is still developing. The increasing area of land will affect the production of shrimp which is increasing. Some of the problems that exist include non-optimal land use, incompatibility of location and farming processes, and misalignment between relevant stakeholders. If this activity continues, it can damage the ecological system, and there is no sustainability.

\section{Acknowledgements}

Thanks to Mr. Indarto as the head of the Cilacap District Fisheries Office Aquculture Division, Fishery Instructor of related sub-district, and farmers for the technical assistance and data provided.

\section{References}

1. T. Beatley, D.J. Brower, A.K. Schwab, An introduction to Coastal Zone Management (Island Press, Washington, 2002)

2. B. Triyatmo, SPs, Thesis Yogyakarta (ID): Gadjahmada University, (2012)

3. FAO, Food and Agriculture Organization of the United Nations, 13 (FAO, Rome, 2020)

4. DJPRL, Ministry of Marine Affairs and Fisheries Republic of Indonesia (KKP, Jakarta, 2021)

5. B. Widigdo, Bertambak Udang dengan Teknologi Biocrete (Kompas Media Nusantara, Jakarta, 2013)

6. DJPDSPKP, Ministry of Marine Affairs and Fisheries Republic of Indonesia (KKP, Jakarta, 2018)

7. Utojo, A. Mustafa, Rachmansyah, Hasnawi, J. Ris. Akuakultur, 4, 407-423 (2009)

8. P.A.I. Tohari, Suadi, Subejo, J. Perikanan Univ. Gadjah Mada, 22, 55-62 (2020)

9. Suadi, H. Saksono, Research Report on Grants from the Faculty of Agriculture, Gadjahmada University (2014)

10. I. Febriansyah, A.A.D. Suryoputro, M. Helmi, J. Oceanogr., 1, 139-148 (2012)

11. D. G. Bengen. PKSPL IPB (PKSPL, Bogor, 1998)

12. G. Handoyo, A.A.D. Suryoputro, I. Pratikyo J. Kelaut. Tropis, 18, 112-120 (2015)

13. M.P. Suhana, Dinamika Maritim, 6, 9-11 (2018)

14. A.F. Kasari, H. Effendi, Sulistiono, Proceedings of the 9th National Fish Seminar, 13 (2017)

15. T.F. Hakiki, I. Setyobudiandi, Sulistiono, Omni-Akuatika, 13, 163-179 (2017)

16. E. Istiyanti, A. R. Saputra, Widodo, Proceedings National Seminar Muhammad University of Yogyakarta (2019) 
17. A.S. Siregar, T.A. Romdoni, N.A. Prayogo, IOP Conf. Ser. Earth and Environ. Sci, 255, 1-7 (2019) 